\title{
'You know, Ernest, the rich are different from you and me': a comment on Clark's $A$ Farewell to Alms
}

\author{
DEIRDRE N. MCCLOSKEY I \\ University of Illinois at Chicago, 60I S. Morgan, Chicago IL 60607, USA, \\ deirdre2@uic.edu
}

The American novelist Scott Fitzgerald is supposed to have said once to Ernest Hemingway, 'You know, the rich are different from you and me.' Hemingway replied, 'Yes. They've got more money.' Gregory Clark is of the Fitzgerald school. Most economic historians, among them his critics, follow Hemingway instead.

Clark modestly sub-entitles his book 'A Brief Economic History of the World'. Brief indeed. In one-and-a-half pages towards the middle he deals briskly with the numerous alternatives to his materialist and richness-admiring hypothesis: 'Social historians may invoke the Protestant Reformation,... intellectual historians the Scientific Revolution... or the Enlightenment... But a problem with these invocations of movers from outside the economic realm is that they merely push the problem back one step. ${ }^{2}$

That's a very good point. Always a good point. Yes, indeed, one may properly ask why 'after more than a thousand years of entrenched Catholic dogma' - set aside that such a view of Christian theology might be viewed as a trifle lacking in nuance, derivative in fact from anti-Catholic propaganda since Voltaire - 'was an obscure German preacher able to effect such a profound change in the way ordinary people conceived religious beliefs?'

Clark, however, like doubting Pilate, does not stay for an answer. $\mathrm{He}$ readily admits that 'ideologies may transform the economic attitudes of societies'. But he has no scientific interest in the causes of ideologies, unless they fit his notion of the material (if social) inheritance of acquired characteristics ('and perhaps even the genes', says he). Clark does not appear to have cracked a book on the history of the Reformation, or on the Scientific Revolution, or on the Enlightenment. So to get rid of such pesky cultural

\footnotetext{
I The piece was delivered to the Social Science History Association in November 2007. It will become some pages of my book, Bourgeois Towns: How Capitalism Became Ethical, I600-I776, which may be read in draft at deirdremccloskey.org.

${ }^{2}$ Clark 2007, pp. 183-4.
} 
variables he reaches at once for a Materialist Lemma: 'But ideologies are themselves the expression of fundamental attitudes in part derived from the economic sphere.' Ah. Only the phrase 'in part', a fleeting tribute to intellectual balance, keeps his sentence from being orthodox historical materialism. As a pair of historical materialists put it in I848:

Man's ideas, views and conceptions, in one word, man's consciousness, changes with every change in the conditions of his material existence, in his social relations and in his social life. What else does the history of ideas prove, than that intellectual production changes its character in proportion as material production is changed? 3

The intellectually temperate phrase 'in part' in Clark's sentence is not cashed in. Rather, the check is immediately and absentmindedly torn up before our eyes. 'There is, however,' Clark declares in the next sentence, 'no need to invoke such a deus ex machina' as a change in ideology, because his own chapter 6 fully explains on materialist grounds, with its own deus (high breeding rates among the rich), 'the forces leading to a more patient, less violent, harder-working, more literate, and more thoughtful society', namely, the bourgeois society we all so admire. In Clark's book, that's the end of ideology.

Such evidence-poor side-remarks evince a historical rhetoric prevalent between I9IO and I980 that man's consciousness changes with every change in the conditions of his material existence, and only with such changes. Thus Durkheim in The Elementary Forms of Religious Life in 1912 argued that ritual, not doctrine, was the heart of religion, because ritual performed the latent function of unifying a society. Compare Anne McCant's recent claim on slender evidence that a compassionate motivation for transfers from the Dutch wealthy to the poor is 'unlikely' and 'can be neither modeled nor rationally explained', or Hugh Trevor Roper's axiom in 1940 that 'in politics [prudence-only political ambition] is naturally by far the most potent' cause, or indeed Engels's claim that 'interests, requirements, and demands of the various classes were concealed behind a religious screen' ${ }^{4}$ After all, what else does the history of ideas prove? That ideas don't matter. Look at the history of stoicism or Protestantism or the abolition of slavery. All of them, you see, were motivated by material causes. Surely.

What Clark does pay out in hard cash is his materialist explanation of the change in English behavior. The argument goes like this:

For England. ... I250-1800. ... the richest men had twice as many surviving children as the poorest... The superabundant children of the rich had to ... move down ... Craftsmen's sons became laborers, merchants' sons petty traders, large landholders' sons smallholders... Patience, hard work, ingenuity, innovativeness,

${ }^{3}$ McCants (1997, pp. 2, 4, 5) and Trevor-Roper (I940, p. 3). The Marx and Engels is 1848 (1988, the Norton edition, p. 73).

${ }^{4}$ Engels, in a Marx and Engels collection, On Religion (Atlanta: Scholars Press, 1964), quoted in Stark (2003, p. 6I). 
education ... were thus spread biologically throughout the population... The embedding of bourgeois values into the culture... [in] China and Japan did not move as rapidly because ... their upper social strata were only modestly more fecund ... Thus there was not the same cascade of children from the educated classes down the social scale... England's advantage lay in the rapid cultural, and potentially also genetic, diffusion of the values of the economically successful through society. ${ }^{5}$

The means of (re)production determine the superstructure. Rich people proliferated, and by a social Darwinian struggle the poor and incompetent died out, leaving a master race of Englishmen to conquer the world.

Certainly it's a bold hypothesis, and was bold when first articulated by social Darwinists late in the nineteenth century. Clark defends it energetically, if narrowly. In fact, if the hypothesis were true it would fit smoothly with my own argument in a forthcoming book that a rhetorical change made the modern world. Clark says that 'there must have been informal, self-reinforcing social norms in all preindustrial societies that discouraged innovation'. ${ }^{6}$ Precisely: the norms of anti-bourgeois aristocrats and clerics did discourage capitalism, until the Venetians temporarily, the Dutch more than temporarily, and at last the English and Scots permanently repealed the norms.

Wrote John Milton in I644, books and ideas 'are as lively, and as vigorously productive, as those fabulous dragon's teeth; and being sown up and down, may chance to spring up armed men', or wealthy merchants. ${ }^{7}$ The Levellers of the I640s, writes David Wootton, 'did not envisage a commercial society of the sort that was actually dominant in early Stuart England, a society of chartered companies and great capitalists; they hoped rather to establish a nation of shopkeepers'. All their other proposals, what Wootton calls an 'extraordinary paradigm shift, which marks the birth of modern political theory' - universal manhood suffrage, a written constitution, non-selfincrimination (freedom from waterboarding, we would say), right to counsel, freedom of religion, freedom of speech - took centuries to establish. ${ }^{8} \mathrm{But}$ a definite move towards freedom of internal trade, for poor people as well as rich, actually came to pass in the lifetime of the last Leveller. Thus mere 'rhetoric'.

Clark, admitting though he does that such rhetoric may transform economic attitudes, would nonetheless wisely urge us to push the problem back one more step: why the rhetorical change? A very good point, I repeat, always a good point. It would imply, if we were committed to historical materialism, that some cause in the means of reproduction must be sought for the rhetoric. Under the Materialist Lemma a rhetoric never changes independent of economics - certainly not by causes within rhetoric itself such

5 Clark 2007, pp. 7-8, II, 27 I.

${ }^{6}$ Clark 2007, p. 165.

7 Milton I644, p. 201.

${ }^{8}$ Wootton I992, p. 83 . 
as the invention of the novel or the logic of Pascal-Nicole-Bayle in theology; not even by such causes as the political settlement in England of 1689, or the obsession with Protestant egalitarianism of all believers in Holland and Scotland from the mid-sixteenth century, or the ordinary man's involvement in politics in Holland, England and Scotland 1585 to I660, or the chances of war that left the New Model Army in possession of the king and the country in I645. Any non-economic and especially any merely rhetorical change is always to be derived from the economic sphere. Intellectual production changes its character in proportion as material production is changed.

Clark is a competent scientist, and produces much evidence with which other scientists agree. It is crucial to distinguish the good arguments from the bad in his book, lest anyone think that the good arguments do much to support the bad. They don't. Much of the book is uncontroversially good, a very good review for outsiders of what economic historians have learned since, say, Karl Polanyi. ${ }^{9}$ We all, we economic historians nowadays, agree that down to the seventeenth or eighteenth century England was trapped as the world has been since the caves in a Malthusian logic. There was no rapid innovation, so that more mouths always mean less bread per mouth, quite soon, and the life of man was brutish and short. We all agree that the escape from the Malthusian trap is the most important event in world history, and we agree on the magnitude of the escape. In the teeth of gigantic increases in population 'the richest modern economies are now ten to twenty times wealthier than the 1800 average' ${ }^{10}$ We agree that innovation, not capital accumulation, was its cause. We agree that it happened first in Holland and England and Scotland. We agree that in China and especially in Japan there were some signs c. I600 that it might happen there, and some of us think that it was Qing and Tokugawa lack of freedom and egalitarianism

${ }_{9}$ Clark does have a problem with acknowledging other scientists. Pages $232-3$ use without citation my design for a decomposition of growth during the Industrial Revolution (McCloskey I98I), and throughout he uses notions of bourgeois virtues (pp. II, 262) with which I am associated, without citation to my work (McCloskey 1994, 2006). As late as early November 2007 Clark gave a speech at the Salk Institute, with me sitting there, the only other economic historian in attendance, in which he explained his own way of measuring the European fall of interest rates $1300-1600$ (pp. 167-75 in his book) without mentioning that $\mathrm{I}$ had discovered the fall and measured it in another statistical way ten years before he did (McCloskey and Nash 1984). Though of course one is best at detecting such slights of one's own work, I detect scores of these for other authors, too. It is a reliable way of making scientific enemies for life. But let's be easy. Clark most engagingly summarizes an enormous scientific literature, and if he gets any substantial number of non-economic intellectuals innocent of economic history to grasp what we other students of such matters all know happened from 1600 to the present we will in our great-heartedness forgive him. The trouble with this hope is that his distinctive hypothesis is going to appeal mainly to the Steve Sailers, Stephen Pinkers and Seth Roberts of the world, and is going to repel everyone else.

io Clark 2007, p. 2. 
and the hostility to the honoring of merchants that stopped it. We agree that since then the rewards to labor have increased and the rewards to capital and land have fallen, contrary to the predictions of the classical economists, including Marx. We agree that the poor of the world have been the largest beneficiaries of the escape from the Malthusian trap. We agree, in other words, on a great many findings from 1944 to the present that will strike the average devotee of Karl Polanyi or Louis Althusser or Barbara Ehrenreich as bizarre and counterintuitive. Geoffrey Sampson makes a similar point in his devastating rebuttal of the linguistic theories of 'nativism' in Stephen Pinker:

I should say to start with that I am far from wanting to contradict every point that Pinker makes in his book. Quite a lot... has little or nothing to do with the nativism issue and is not at all controversial, at least not among people versed in the findings ... It is possible to read The Language Instinct [and A Farewell to Alms] as a general survey. ${ }^{\mathrm{II}}$

Just so.

What other historical scientists do not agree with, however, is Clark's only distinctive argument, that English people became by virtue of their rate of breeding a race of Übermenschen living in an Übergemeinschaft. One of the few historical scientists with whom Clark agrees on the matter is David Landes, whom he commends briefly for being 'correct in observing that the Europeans had a culture more conducive to economic growth' though Landes thinks the superior culture had more ancient sources than the breeding rates of late medieval families. ${ }^{12}$

Of the distinctive part of Clark's book there are a lot of criticisms to be made - so many that it is going to have to be abandoned.

For one thing, non-European places have grown, after the example of Holland and England and Scotland. As the Nobel economist Robert Solow wrote in his scathing review of the book:

Clark's pessimism about closing the gap between the successful and less successful economies may derive from the belief that nothing much can change unless and until the mercantile and industrial virtues seep down into a large part of the population, as he thinks they did in preindustrial England. That could be a long wait. If that is his basic belief, it would seem to be roundly contradicted by the extraordinary sustained growth of China and, a bit more recently, India. Embarrassingly for Clark, both of those success stories seem to have been set off by institutional changes, in particular moves away from centralized control and toward an open-market economy. (Solow 2007)

Not the commercial virtues inherited by people but the virtues praised by people is what's required. China repealed its law against millionaires and India started admiring entrepreneurs, and both were off to the races.

For another, non-Europeans, those Untermenschen, became astoundingly rich when they moved into places in which bourgeois values are honored.

\footnotetext{
II Sampson 2005, p. IIO.
}

I2 Clark 2007, p. II. 
It has nothing to do with inherited values. Clark shows little interest in American economic history, which is the main instance. Nor does he consider the numerous diasporas of Chinese or Armenians or whomever who enriched themselves away from the kingly chaos and aristocratic oppression of their homelands. He also shows little interest in his native Scotland, which did have an Industrial Revolution, but had as recently as the century before its revolution nothing like England's 'extraordinary stability', partly indeed because of repeated invasions and other fishing in troubled waters by the stability-enjoying English. Nor does he show interest in my own ancestors, the Irish, who, when they crossed the Irish Sea to staff the cotton and wool mills that he investigates with such empirical imagination, became instantly the good workers who couldn't of course ever arise from such a turbulent and demographically unsound place as Ireland, which did not have an Industrial Revolution.

But the main failure of his hypothesis is, oddly, that a book filled with ingenious calculations, hundreds upon hundreds of them exhibiting Clark's historical imagination - that quality of asking questions and seeing your way to answering them - does not calculate enough. It doesn't ask or answer the crucial historical questions. The argument can be diagrammed like this, as four states $I, 2,3,4$ linked by three causal and transforming causal arrows $A, B, C$. Notice the bold entries:

\section{The Clark hypothesis: Rich people are better and drive out the poor}
$\boldsymbol{I}$.
$A$.
2.
$B$.
3.
C.
4.
Rich breed $\rightarrow$ Rich people's $\rightarrow$ More patience, $\rightarrow$ Enrichment more values spread work, ingenuity of all

The two large and bolded states at the ends, $I$ and 4, get satisfying amounts of empirical attention. Clark's writing on state 4 especially is conventional but, as I said, good. State 4, about which I repeat we all agree and on which all of us have worked and of which it is most important that we persuade non-economic intellectuals, is nailed.

Yet Clark insists throughout on hammering on exclusively quantitative nails. So he skimps on state 3 and especially on state 2 . Clark, who believes that when you cannot measure, your knowledge is meager and unsatisfactory, is not comfortable with literary and other 'ego-document' sources, as German historians call them nowadays. And so he does not realize that written sources can themselves be counted, and in any case that how people speak is part of the empirical evidence. That Jesus said 'render unto Caesar' is part of the empirical evidence about early Christianity's relationship to the state. That Luther said 'one prince, one faith' is similar evidence in 
the Reformation. In consequence of Clark's aversion to words he does not have much to say about how one would know that 'informal, self-reinforcing social norms' of rich people had spread. Therefore on state 2 he is very, very thin.

State 3 gets more attention, sometimes of a quantitative sort - South Asian workers work less, for example; and, as Jan de Vries has put it, there was an 'industrious revolution' of more application to work in first the Dutch and then the English lands during the seventeenth and eighteenth centuries. Clark follows Mokyr and others, as I do, in emphasizing the ingenuity of inventors in cotton and iron and so forth, and uses a table which I devised in $198 \mathrm{I}$ to show that the ingenuity in England I780-I860 was in fact evident beyond such heroic industries. ${ }^{13}$

What is entirely missing, however, are calculations justifying the links A, B, C between the states. That's the big problem. Clark notes for example that in countries with ill-disciplined labor forces, such as India, the employer doesn't get as much output as in England, because the non-bourgeois values of the Indian workers and the employers leave not enough 'work' in the diagram. But the 'as much' and 'not enough' are nothing like the 20 to 30 times gap between poor India and rich England that he claims to be explaining. That is, Clark has failed to show how much Enrichment depends on Work, state 4 on state 3. He hasn't done a calculation on the size of C. He hasn't asked about its oomph. And so he naturally has no answer.

Nor does he do a calculation on link $B$, to show that state 3 depended mightily on state 2 , that, say, ingenuity depended on the spread of bourgeois values. It's deucedly hard to do. I myself agree the link was very important yet I can't think of ways to quantify it, and have had to rely instead on the metaphysically unsatisfactory but enormously rich and ubiquitous qualitative evidence which Clark spurns and which the other students of ingenuity such as Mokyr have exploited. Given his methodological rule of number, Clark is not to blame that even his admirable if strictly quantitative historical imagination is stymied by the question of how much bourgeois values acted to increase ingenuity. Still, his methodological stridency about number does make it embarrassing that he doesn't even mention that for link $B$ he can't provide numbers. We fools like Jack Goldstone or Deirdre McCloskey who merely listen to what people at the time were saying about $B-$ get a certain satisfaction that Clark is thus hoist by his own methodological petard.

In light of Clark's methodological convictions, though, the most embarrassing broken link is $A$, between 'Rich breed more' and 'Rich people's values spread.' Nowhere in the book does Clark calculate what higher breeding rates could have accomplished by way of rhetorical change. It could

${ }^{13}$ Mokyr I990, 2002; the table is Clark 2007, p. 233. 
easily be done, at any rate under his mechanical assumption about how the social construction of values works. Clark assumes that the children of rich people are by that fact carriers of the sort of bourgeois values that make for an Industrial Revolution.

To be sure, this is an odd characterization of the medieval or early modern relatively rich. A rich bourgeois of London in I400 devoted most of his effort to arranging special protection for his wool-trading monopoly. His younger sons might well have taken away the lesson, repeated again and again down to Elizabethan England and Lou Dobbs, that it's a good idea to regulate everything you can, and quite a bad thing to let people freely make the deals they wish to make. And a Brave Sir Botany who had stolen his riches, say, or who was a successful courtier receiving them from Henry VIII out of dissolved monasteries, say, would not automatically, one would think, transmit sober bourgeois values to younger sons. A society that extravagantly admired aristocratic or Christian virtues could corrupt even a Medici banker into thinking of himself as quite the lord and yet also a godly son of the Church. In a similar way nowadays an extravagant admiration for the neo-aristocratic values of the clerisy corrupts the bourgeois daughter into scorning her father's bourgeois occupation.

Clark, you see, is intrigued by neo-Darwinian theories applied to society. He believes that the bourgeois-behaving unit of meaning, a 'meme' as some of the theorists call it, spreads strictly from parents to children, like eye color. But the biological analogy here is very strange, and after the sixteenth century gets stranger and stranger the cheaper and less regulated European publishing becomes and the wider grammar schools spread (thus Shakespeare, son of a glover) and the universities (thus Kant, son of a saddler) and, to step down to the real bourgeoisie, the proliferating schools for young merchants. If solidly bourgeois behavior was such a good idea for making people rich you would think it would spread by imitation, across families, as from Defoe's Essay Upon Projects (I697), which Benjamin Franklin cited as an influence, or from the hundreds of handbooks for youths in business from the sixteenth century on. The research biologist and professor of theology Alistair McGrath notes that recent work on genome sequencing has shown that the simplest forms of life trade genes contemporaneously. So do the most complex and cultural forms of life, such as seventeenth-century Europe. To apply genetics to cultural memes, he remarks, one would have to concede that 'the origins of Renaissance humanism [say] ... were deliberate, intentional, and planned. If Darwinism is about copying the instructions,... Lamarckism is about copying the product ... It would seem that Lamarck, rather than Darwin, offers the better account of cultural evolution.' ${ }^{2} 4$

${ }^{14}$ McGrath 2007, p. I27, italics deleted; p. 4I on genome sequencing. 
But leave aside the actual, empirical stories of how values are made. Clark's lack of curiosity about the exact content of bourgeois values (values which, I repeat, he and I join in admiring) leaves him, I say, with a mechanical, neo-Darwinian and extremely dubious model of how values get transmitted. But suppose his mechanical model is correct. Then a scientist of Clark's quantitative ingenuity would have found it trivial to calculate, mechanically, what the higher rates of breeding would yield in bourgeois-minded but lowerclass people in the next generation. He didn't.

The underlying problem is that Clark wants his story to be very long-run, because he has ambitions for its endogeneity, which is to say its historical materialism. He wants bourgeois values and the modern world to arise with slow-chapped pow'r out of a thousand years of English history. No dei ex machina, thank you very much - by which he means short-run and therefore contemptible events like the birth of English political freedom or the Protestant Reformation or the Scientific Revolution.

Why is his long-run ambition a problem for his story? Because his mechanical model of the transmission of values works too quickly, on a scale of a century or so-not ten centuries. Then it dissipates. Regression to the mean alone would strictly limit the effect to a few generations. After all, we say 'clogs to clogs' or 'shirt-sleeves to shirt-sleeves' in merely three. As Francis Galton put it in making a similar calculation - Galton in I90I got quantitatively further than Clark - very high inherited height or intelligence or bourgeois virtue dissipates strongly in children and more in grandchildren, 'owning to the combination of ancestral influences - which are generally mediocre with the purely parental ones'. ${ }^{15}$ Galton was part of Darwin's family, first notable in Erasmus, Charles's and Francis's grandfather. But their sons and daughters regressed. That puts paid to his long-run story. As the economist Samuel Bowles put it:

If $\mathrm{h}^{2}=0.26$ the correlation across 4 generations (great-grandfather-great-grandson) is 0.032 . If we estimate $h^{2}$ from the observed intergenerational correlation of traits ( $r$ ) as above, then the correlation of a genetically transmitted trait across $n$ generations is just $\mathrm{r} / 2^{\mathrm{n}-2}$. Thus the statistical association across generations becomes vanishingly small over the course of a single century, whether the trait is culturally or genetically transmitted. (Bowles 2007)

Clark describes his central chapter 6 as identifying 'strong selective processes' ${ }^{16}$ That's the problem: they are too strong for a slow story, and so his own argument, were it true, would turn out to be one of the despised dei ex machina that work on a scale of decades or a few generations or a century at most. If he had followed his rule of number and had tried to calculate the oomph of link $\boldsymbol{A}$ he would have caught the scientific oversight before announcing to the world, against the evidence and the logic followed by

I5 Galton I90I, p. I5.

I6 Clark 2007, p. I83. 
everyone else in his field, that he had solved the leading scientific question in economics. Embarrassingly, he did not do the calculations.

Consider for example one of the bourgeois values we can measure, and Clark does, again with his usual quantitative insight, literacy. Male literacy in England, Clark reports, rose from the share of monks in the male population in, say, I300 (though illiterate monks were by no means unknown; among the secular clergy illiteracy was commonplace) to perhaps 30 percent in I580 and to 60 percent by the time national statistics start to be possible in the I750s.

Think about it. If you are the parent of four children, and can read, what is the transition probability that all four of your children will read? It is extremely high, at any rate in a society that for some reason values literacy. Thus in families today 'going to college' is extremely inheritable, but in one generation. Unlike my Irish ancestors, my Norwegian ancestors on the Hardanger Fjord were reading by the late sixteenth century, and never stopped. Why? Clearly, because of that Protestant Reformation, a literal deus, to which Clark in his book explaining modern Europe allots eight words. No religion, please: we're demographic historical materialists. The impoverished Norwegians (no bourgeois virtues there, right?) learned to read quickly. The habit spread across families. And once in a family it stayed there.

So Clark's socio-neo-Darwinianism, which he appears to have acquired from a recent article by some economic theorists, has as little to recommend it as history. It's cute, it attracts a lot of attention. But it's wrong.

An early version of Clark's hypothesis may be examined in Galton's Huxley Lecture to the Anthropological Institute in I90I:

\begin{abstract}
The number and variety of aptitudes, especially in dogs, is truly remarkable ... So it is with the various natural qualities that go towards the making of civic worth in man (p. 3) ... The brains of the nation lie in the higher of our classes (p. II) ... Dr. Farr, the eminent statistician, endeavored to estimate the money worth of an average baby born to the wife of an Essex laborer... Dr. Farr, with accomplished actuarial skill, capitalized the value at the child's birth... [It] was found to be $£ 5$. On a similar principle the worth of an X-class baby would be reckoned in thousands of pounds... They found great industries, establish vast undertakings, and amass large fortunes for themselves. Others, whether they be rich or poor, are the guides and light of the nation (pp. I I-I2).... Many who are familiar with the habits of [the lowest class] do not hesitate to say that it would be an economy and a great benefit if all habitual criminals were ... peremptorily denied opportunities for producing offspring (p. 20)... The possibility of improving the race of a national depends on the power of increasing its best stock (p. 24).
\end{abstract}

This sort of reasoning was all fresh and new in I90I, and was still influential after the Great War, resulting in places like Norway, Sweden and the United States in compulsory sterilization programs, brought to an end only in the I970s. It even survived its application in Germany. It still attracts the quantitative and mechanical mind. It's neat. It's formalizable. It's calculable (though, I repeat, Clark has not followed the calculations that Galton showed how to do). 
But it doesn't make any sense. It depends on measures of aptitudes that are, like height, influenced by more than inheritance and, unlike height, have no natural units invariant to society. What made for riches in 1600 had little to do with what made for riches in 2000. A graceful way with sonnets and a good leg for bowing are not similar to a Harvard MBA and a knack for computers. What mattered in modern economic growth was not a doubtfully measured alteration in the abilities of English people but a radical change from I600 to I776, 'measurable' in every play and pamphlet, in what England wanted, what England paid, what England valued.

\section{References}

BOwLES, S. (2007). Genetically capitalist? Review of Farewell to Alms. Science $3 \mathbf{I 8}$ (5849), pp. 394-6.

Clark, G. (2007). A Farewell to Alms: A Brief Economic History of the World. Princeton: Princeton University Press.

GaLTON, F. (I9OI). The possible improvement of the human breed under existing conditions of law and sentiment. Huxley Lecture to the Anthropological Institute, printed as pp. I-34 in Essays in Eugenics. London: Eugenics Education Society.

MCCANTs, A. E. C. (1997). Civic Charity in a Golden Age: Orphan Care in Early Modern Amsterdam. Champaign: University of Illinois Press.

MCCloskey, D. N. (198I). The Industrial Revolution, I780-1860: a survey. In R. Floud and D. McCloskey (eds.), The Economic History of Britain, I70o-Present. Cambridge: Cambridge University Press, vol. I, pp. I03-27.

MCCloskey, D. N. (1994). Bourgeois virtue. American Scholar 63 (2), pp. I77-91.

MCCloskey, D. N. (1998). Bourgeois virtue and the history of P and S. Fournal of Economic History 58 (2), pp. 297-317.

MCCloskey, D. N. (2006). The Bourgeois Virtues: Ethics for an Age of Commerce. Chicago: University of Chicago Press.

MCCloskey, D. N. and NASH, J. (1984). Corn at interest: the extent and cost of grain storage in medieval England. American Economic Review 74, pp. 174-87.

MCGrath, A. (2007). Dawkins' God: Genes, Memes, and the Meaning of Life. London: Blackwell.

Milton, J. I644 (1985). Areopagitica. In C. A. Patrides (ed.), fohn Milton: Selected Prose, revised edn. Columbia: University of Missouri Press, pp. 196-248.

MOKYR, J. 1990. The Lever of Riches. New York and Oxford: Oxford University Press.

MOKYR, J. 2002. The Gifts of Athena: Historical Origins of the Knowledge Economy. Princeton: Princeton University Press.

SAMPSON, G. 2005. The 'Language Instinct' Debate, revised edn. London and New York: Continuum.

Solow, R. (2007). Survival of the richest? New York Review of Books 54 (I8).

TreVOR-Roper, H. (1940). Archbishop Laud, 1573-1645. London: Macmillan. Wootton, D. (1992). The Levellers. In John Dunn (ed.), Democracy: The Unfinished fourney, 508 BC to AD 1993. Oxford: Oxford University Press, pp. 7I-89. 